Research Report No. 17/2008

\title{
The BCE Decision: Reflections on the Firm as a Contractual Organization
}

Peer Zumbansen

Osgoode Hall Law School of York University, PZumbansen@osgoode.yorku.ca

S. B. Archer

Follow this and additional works at: http://digitalcommons.osgoode.yorku.ca/clpe

\section{Recommended Citation}

Zumbansen, Peer and Archer, S. B., "The BCE Decision: Reflections on the Firm as a Contractual Organization" (2008). Comparative Research in Law \& Political Economy. Research Paper No. 17/2008.

http://digitalcommons.osgoode.yorku.ca/clpe/191 
Peer Zumbansen and Simon Archer The BCE Decision: Reflections on the Firm as a Contractual Organization

EDITORS: Peer Zumbansen (Osgoode Hall Law School, Toronto, Director, Comparative Research in Law and Political Economy, York University), J ohn W. Cioffi (University of California at Riverside), Lindsay Krauss (Osgoode Hall Law School, Toronto, Production Editor)

This paper can be downloaded without charge from the Social Science Research Network Electronic Library at: http:/ / ssrn.com/ abstractid=1160094 

CLPE Research Paper 17/2008

Vol. 04 No. 04 (2008)

\title{
Peer Zumbansen and Simon Archer
}

\section{THE BCE DECISION: REFLECTIONS ON THE FIRM AS A CONTRACTUAL ORganization}

\begin{abstract}
The authors discuss the decision of the Supreme Court of Canada to approve a plan of arrangement privatizing BCE Inc. over the objections of bondholders. Summarizing the arguments for "shareholder primacy" and debenture covenants delimiting contractual rights against boards and management, they argue that an expanded conception of relational contract theory is useful in analyzing the competing claims in the BCE deal and litigation. This approach requires that broader contextual factors are necessary to consider in the functioning of the corporation, especially by after-the-fact decision-makers.
\end{abstract}

Keywords: Corporate theory; takeovers; shareholder primacy; contracts; nexus-of-contracts, stakeholder theory of the corporation; relational contract theory; transnational law; legal pluralism.

JEL classification: K20, K22

Peer Zumbansen

Associate Dean (Research, Graduate Studies \& Institutional Relations).

Director, Critical Research Laboratory in Law \& Society

[www.criticalresearchlab.org]; Co-Editor in Chief, German Law Journal

[www.germanlawjournal.com]

Osgoode Hall Law School, York University, Toronto ON

Email: pzumbansen@osgoode.yorku.ca

Simon Archer

CLPE Research Fellow

Osgoode Hall Law School, York University, Toronto ON

sarcher@osgoode.yorku.ca 


\title{
THE BCE DECISION: REFLECTIONS ON THE FIRM AS A CONTRACTUAL ORGANIZATION
}

\author{
Peer Zumbansen ${ }^{*}$ and Simon Archer ${ }^{* *}$
}

\section{THE SCC DECISION AND THE BCE DEAL}

On June 20 ${ }^{\text {th }}$, 2008 the Supreme Court of Canada (SCC) over-turned the Quebec Court of Appeal (QCA) ${ }^{1}$ holding that the plan of arrangement taking BCE Inc. (BCE) private did not improperly neglect a subsidiary's (Bell Canada) bondholders' interests. The heavily leveraged (\$30B) buyout of shareholders claims $(\$ 51.7 \mathrm{~B})$ will proceed next December, if all goes well. That's a big deal.

The decision was widely applauded if not expected in corporate law firms and boardrooms. ${ }^{2}$ The Court in Ottawa has not yet released reasons, and may not until the autumn. It is and will be one of the most discussed corporate law decisions since the SCC's Peoples $v$. Wise ${ }^{3}$ decision of 2004, which will almost certainly be revisited and, we expect, distinguished.

There are so many interesting facets of the BCE deal, but most of the commentary before and after the BCE decision has focused on the

\footnotetext{
* Canada Research Chair, Osgoode Hall Law School, Toronto. Email: Pzumbansen@osgoode.yorku.ca

** CLPE Fellow, Osgoode Hall Law School, Toronto. Email: sarcher@osgoode.yorku.ca.

${ }^{1}$ [2008] Q.C.C.A. 935. There are no reasons released for the SCC decision at the time of writing.

2 DeCloet, D., “A Victory for sanity, capitalism and common sense”, Globe and Mail, June 21, 2008, available online at http://www.theglobeandmail.com/servlet/story/LAC.20080621.RDECLOET21/TPStory/ TPBusiness/?query= (last visited June 30, 2008).

${ }^{3}$ Peoples' Department Stores Inc. (Trustee of) v. Wise, [2004] 3 S.C.R. 461 [hereinafter Wise]; available online at http://scc.lexum.umontreal.ca/en/2004/2004scc68/2004scc68.html (last visited 30 June 2008).
} 
importance of "shareholder primacy" in certain transactions and the role of contract law in delimiting bondholders' rights. The main thrust of the commentary is that shareholder wealth maximization should be the standard which boards meet in these types of takeover transactions. Bondholders can contract the terms they need, so if things don't go right, caveat emptor. At times, these two features are said to be essential to the functioning and even existence of free market capitalism. ${ }^{4}$ That burdens the case with more weight than is warranted. It does, though, indicate that the SCC must delve even deeper into an area it has largely managed to avoid.

The SCC's relatively rare interjection into the heart of corporate law where angels fear to tread - is the more remarkable as corporate law has become one if not the most intensively contested regulatory areas. Once thought of as a relatively sleepy and uneventful domain, corporate law has become a focus of new tensions. As corporate activities increasingly globalize under the pressure of knowledge, production and distribution flows, their regard to national boundaries ${ }^{5}$ becomes less and less. Technological change and industrial composition change rapidly, processes even more exacerbated by the crucial impact of what is sometimes termed the "financialization" of capitalism. ${ }^{6}$

The BCE deal is in many ways a product of these factors, but we have not heard quite as much about them in the legal commentary to date. It is worth mentioning some of them before we turn to more narrowly constructed legal issues before the Court.

\footnotetext{
${ }^{4}$ MacIntosh, J., “The People’s corporate law, unsafe at any speed”, Financial Post, June 10, 2008 available online at http://www.law.utoronto.ca/visitors_content.asp?itemPath=5/5/0/0/0\&contentId=1752 (last visited June 30, 2008).

5 See only Lynn, B. C., END OF THE LiNE. THE RISE AND FALL OF THE GLOBAL CORPORATION (Doubleday: New York 2005); hereto Kennedy-Stewart, F. in (2007) 8 GERMAN LAW JOURNAL 1091, available at http://www.germanlawjournal.com/pdf/Vol08No11/PDF_Vol_08_No_11_10911108_Developments_Kennedy-Stewart.pdf

6 Foster, J., "The Financialization of Capitalism" in (2007) 58:1 Monthly Review available online at http://www.monthlyreview.org/0407jbf.htm (last visited June 30, 2008).
} 


\section{THE DEAL IN WIDER CONTEXT}

$\mathrm{BCE}^{7}$ itself is a former regulated monopoly in a now deregulated telecommunications industry that has seen very dynamic economic change in the past 10 years. BCE provides communication services to residential and business customers in Canada. Its services include landline and wireless phone services, internet and broadband services, information and communications technology services, and satellite and VDSL television services.

The BCE deal is the largest-ever leveraged buy-out (LBO) in Canadian history: that is, the financing of the deal is largely from borrowed money secured against the business. The purchasers are a consortium of a private equity firm (Cerberus) and a pension fund (Ontario Teacher's Pension Plan). The original deal documents can be found on the July 5, 2007 SEDAR filings, and summarized in the August 14, 2007 circular to shareholders and a summary of the deal structure is available. ${ }^{8}$

The LBO takeover technique was made infamous during the 1980s, especially in the context of hostile takeovers - you may remember Michael Milken funding corporate raiders with high-yield bonds. In fact, it was in just one of those takeovers, the Ronald Perelman takeover of Revlon Inc., that the shareholder primacy argument in the U.S. was tested. The case ${ }^{9}$ was seminal in re-establishing the directors' duty to maximize shareholder wealth in a hostile take-over transaction. It became known colloquially as the "Revlon rule". That rule has since been re-interpreted in U.S. jurisprudence to accommodate other circumstances and types of transactions. But, rather than being a self-evident truth since Henry Ford's day, adopting a policy of shareholder wealth maximization has been occasionally challenged and required intervention from courts to

7 See basic corporate information at Globeinvestor, available online at http://www.globeinvestor.com/servlet/Page/document/v5/data/stock?id=BCE-

T\&pi_sponsor= (last visited June 30, 2008).

8 Both available online: see www.seadar.ca and see http://www.crtc.gc.ca/Broadcast/eng/HEARINGS/2007/ex2007-19.htm for the deal structure (last visited June 30, 2008).

${ }^{9}$ Revlon Inc. v. MacAndrews \& Forbes Holding Inc. (1986) 506 A.2d 173, Fed. Sec. L. Rep. P 92,525, 54 USLW 2483, 66 A.L.R.4th 157. 
determine appropriate circumstances for the application of that duty: we'll say something more about this below.

That LBO era also saw the erosion of corporate bond ratings as debt was piled on to finance transactions, the circumstances surrounding the issue before the courts here. This prior LBO experience is in fact what the appellants point to when they argue that Bell Canada's bondholders knew or should have known the risks they were taking. Since that first big LBO era, many of those same corporate raiders (who avoided jail time) had two decades to acclimatize to the role of proprietors. This time, the BCE deal was a friendly take-over by a respected private equity firm (they also have a stake in Chrysler, for example) and an equally respected pension fund, and was made with the approval of board and management, after considering competing bids.

However, as in the old LBO era, the deal raises questions of how the debt will be paid, what strains it will put on business finances and whether it will be paid at the expense of future re-investment in the firm, product development, $\mathrm{R} \& \mathrm{D}$, improving existing infrastructure, or cuts in other areas: in other words, at the expense of other stakeholders in the corporation. In the past, wages and pensions were top of the list, although one suspects those would be sensitive issues for a majority owner that itself is a pension fund. To date, however, there is not a clearly stated new business direction for the privatized corporation. There are also no clear indications of the exit strategy for the BCE deal, if there is one.

In this particular type of takeover and other M\&As, the intentions and consequences are sometimes characterized as long-term versus short-term. Pension funds are often thought to be long-term investors (although evidence of equity market holdings in the 1990s suggests not always) and private equity houses are thought to be short-term investors (which is where they earned their reputation as "raiders"). It is unclear if one or all of the BCE buyers are in it for the long haul, but we might assume they are.

These two approaches are associated with various metrics by which we can test theories of the overall value of the deal or of types of transactions in general. It is still too soon to tell, and as with so many aspects of markets, we will only know in retrospect. Empirical evidence and other 
academic work have not discerned a clear trend in the longer-term outcomes of this recent spate of privatizations. ${ }^{10}$ Related research on M\&As is inconclusive at best: as measured by share prices, M\&As have not always or consistently been value propositions for purchasers and their stakeholders, especially in the telecom sector. ${ }^{11}$ However, we can say that one of the useful developments in this research is to examine a broader array of business-related measurements such as employment tenure and wages, investment, $R \& D$ as well as the more traditional financial tests of a healthy organization. It will no doubt take a business cycle to test the financial architecture of these deals, if the current credit crunch does not do the job.

Or an exit strategy might involve a short-term sale of the ownership interest to a foreign transnational telecom or conglomerate. There are currently limitations on the foreign ownership of telecoms in Canada, although a recent report ${ }^{12}$ produced for the federal government has recommended repealing those restrictions. In that case, we could see yet another Canadian corporation "hollowed out", making functions moved offshore. This hollowing out is the head office equivalent of manufacturing jobs sent offshore, but this time, it affects senior management and the producer services that go along with senior management: accounting, legal and financial services in particular. Again,

${ }^{10}$ Bratton, W. W., "Hedge Funds and Governance Targets" (2006) Georgetown Law and Economics Research Paper No. 928689 Available at SSRN: http://ssrn.com/abstract=928689 (last visited June 30, 2008).

${ }^{11}$ For examples of this research see Capasso, A.\& O. Meglio, "The Evolving Role of Mergers and Acquisitions in Competitive Strategy Research" (September 20, 2007) available at SSRN: http://ssrn.com/abstract=1015722; Wright, M., Siegel, D. \& D. Cumming,"Private Equity, Leveraged Buyouts and Governance" (2007) Journal of Corporate Finance available at SSRN: http://ssrn.com/abstract=983802; Bouwman, C.H., Fuller, K. \& A. Nain, "Market valuation and acquisition quality: Empirical evidence" (2006) Review of Financial Studies available online: http://web.management.mcgill.ca/Amrita.Nain/index files/RFSforth.pdf; (last visited June 30, 2008).

${ }^{12}$ Competition Policy Review Panel, Compete to Win, Report of the Competition Policy Review Panel, June, 2008 available online at http://www.ic.gc.ca/epic/site/cprpgepmc.nsf/en/Home, (last visited June 30, 2008).

${ }^{13}$ Arthurs, H.W., "The Hollowing Out of Corporate Canada?" available online http://www.yorku.ca/robarts/archives/pub_domain/pdf/apd_arthurs.pdf (last visited June 30, 2008). 
there is debate ${ }^{14}$ about the short and long-term effects of hollowing out, and time (and better empirical work) will tell.

We can perceive, though, a parallel here, as the more corporate governance and organizational design become increasingly driven by financial design and transnational strategy, the more corporate law's traditional regulatory framework is increasingly put under enormous pressure. After several years of intensive, comparative study of national regulatory responses to an ever-more de-territorialized ${ }^{15}$ corporate reality, the particular, transnational nature of corporate governance regulation ${ }^{16}$ as a field populated by a mix of public and private, domestic and supranational norm-entrepreneurs - has become more and more apparent. These background tensions are, or will be, essential to contextualizing the operation of corporations on a daily and practical basis.

\section{REASONABLE EXPECTATIONS OR CAVEAT EMPTOR?}

It may seem odd to recite a series of academic and policy concerns in a commentary about a bondholder dispute with an LBO. The connection will be made presently; but next we turn to the issue that seemed to awaken the corporate legal community from its dogmatic slumber. This was the decision of the QCA to refuse to approve the plan of arrangement, against all expectations.

The core conflict in this decision is between the economic interests of BCE shareholders on one side and the of the BCE debt-holders on the other. The issues before the court were of course narrowly framed - they

\footnotetext{
${ }^{14}$ Hynes, D., Restructuring in a Global Economy: Is Corporate Canada Being Hollowedout? Report for the Conference Board of Canada, June, 2001 available online at http://www.conferenceboard.ca/documents.asp?rnext=71 (last visited June 30, 2008).

15 Hill, J.G., "The Persistent Debate about Convergence in Comparative Corporate Governance” Sydney Law School Research Paper No. 06/3 Available at SSRN: http://ssrn.com/abstract=881896.

${ }_{16}$ Zumbansen, P. "The Parallel Worlds of Corporate Governance and Labor Law" (May 16, 2006) CLPE Research Paper No. 6/2006 Available at SSRN: http://ssrn.com/abstract=902650.
} 
were not asked a policy question but a question of legal interpretation and so naturally discussion reflects this construction. We don't have the SCC's reasons yet, only its decision, but we can discuss the issues with reference to the decision of the QCA and the 2004 Wise decision, which is considered by some to be the real cause for concern. ${ }^{17}$

At the core of the QCA's reasoning is the finding that BCE's board did not give sufficient regard to the interests of the bondholders in structuring the transaction, that is, whether it could have achieved the privatization without such a significant erosion of existing bonds' value. The QCA criticized the proposed plan of arrangement for its failure to be "fair and reasonable" to all security-holders in the circumstances.

The legal basis for this criticism was a provision in the Canada Business Corporations Act (CBCA). ${ }^{18}$ It contains a duty under which directors must consider the interests of all security-holders in approving a plan of arrangement. Bondholders are security-holders by definition, and they therefore sought relief under the oppression remedy, which addresses unfair and unreasonable treatment of corporate constituencies and is recognized in s. 241 of the CBCA.

BCE's procedure by plan of arrangement required that it establish that the plan was "fair and reasonable" within the meaning of s. 192 of the CBCA. A plan of arrangement is a technique for achieving a takeover deal in one step, commonly used in friendly takeovers. It is also used in other reorganizations of corporations, sometimes in the context of insolvencies. The Wise decision was one that involved one of these different contexts an insolvency. The upshot of that decision was that directors should consider the interests of creditor stakeholders of a corporation: at least, they must in the context of a restructuring in the realm of insolvency. The Wise case provided support for the bondholders' arguments in the BCE appeal. There are other distinctions between the two cases: strictly

17 Lee, I.B., "Peoples Department Stores $v$. Wise and the 'Best Interests of the Corporation'” (2005) 41

Canadian Business Law Journal 212; see also Rousseau S. \& P. Desalliers, in their new book 'Les devoirs des administrateurs lors d'une prise de contrôle, étude comparative du droit du Delaware et du droit canadien', which the Appeals Court quotes extensively at paras. [100] ff., for an ongoing interpretation of the Wise judgment.

${ }^{18}$ R.S.C. 1985 c. C-44. 
speaking, the subsidiary was not "in play" in the BCE deal, its parent was. Wise involved a private corporation, not a public one like BCE.

Many of these differences were not mooted by the QCA. In the central passage of its decision, the QCA engages on several fronts with the very theory of corporate law, which critics ${ }^{19}$ readily mobilize in their rejection ${ }^{20}$ of the Court's judgment. Within the statutory framework we have just described, the issue was framed by the QCA as an interpretation of the contractual terms governing the debentures. By employing this framework, the QCA sets itself the challenge of providing a contextual contractual interpretation: in other words, of enforcing the terms of the parties' contract both with regard to the terms themselves, in light of the circumstances in which the contracts were concluded, and the effect of the BCE transaction upon them. In a nutshell, the QCA held that,

reasonable expectations are not limited to the legal rights spelled out in the contractual terms of the trust indentures. However, these expectations, to remain reasonable, cannot run contrary to the express terms of the relevant contracts [emphasis added]. ${ }^{21}$

In this short passage, we find the essence of what makes contract law the enormous enigma ${ }^{22}$ in legal science and practice. The reliance on the parties' intentions is unavoidably always an ambitious act of intervention, whatever the interpreter's intention. ${ }^{23}$ Trying to get the contract's terms right between an interpretation of the contract's terms, but not against what the contract's terms constitutes, is the very challenge that any legal enforcement of contractual arrangements entails.

19 Backer, L.C., "Multinational Corporations, Transnational Law: The United Nation's Norms on the Responsibilities of Transnational Corporations as Harbinger of Corporate Responsibility in International Law" (2005) 37 Columbia Human Rights Law Review available at SSRN: http://ssrn.com/abstract=695641. See also Backer's commentary here: http://lcbackerblog.blogspot.com/2008/05/fiduciary-duty-for-directors-in-canada.html

(last visited June 30, 2008).

${ }^{20}$ Macinstosh, supra note 4.

${ }^{21}$ [2008] Q.C.C.A. 935 at para. 71.

22 Zumbansen, P., "The Law of Society: Governance Through Contract" CLPE Research Paper 2/2007 available at SSRN: http://ssrn.com/abstract=988610.

${ }^{23}$ Fuller, L. 'Consideration and Form', (1941) 41 Colum. L. Rev. 799-824. 
A formal and - as we argue below - reductionist view would restrict any interpretation to the written terms of the contract. In this view, reasonable expectations are limited to those spelled out in the contractual terms, as was urged by the appellants. This view of contracts, as bilateral negotiations that meet a set of legal formalities at a fixed point in time has its advantages, and the concept itself can be expanded through multiplication to accommodate the myriad transactions of a corporation.

Or, a wider view might involve an assessment of director's duties (the statutory duties to security-holders, or the duty to be "fair and reasonable") or even what took place over the course of a business relationship (what the directors said to the bondholders or other stakeholders in the firm in press releases, but did not reduce to contract). The challenge of contractual interpretation is thereby amplified by the organizational context in which the interpretation takes place.

\section{THE CORPORATION AS A CASCADE OF CONTRACTS}

Once we have come this far, we can artificially divide the world into two groups: those who want to look at the contract, the text, and those who want to look at the circumstances around the contract, the unstated expectations or conditions, the changes since the contract, and so-on: in short, the context. Contractual theory and practice can accomplish both, but before turning to those developments, we ought consider the implication of examining contracts in corporate structures and corporate structures as contracts both in the narrow sense.

Commentators such as Professor MacIntosh rejected the QCA (and Wise) decision, recognizing in the QCA's approach nothing but a misunderstanding of the "true" theory of the firm. The firm, he and they suggest, is much more like a "nexus of contracts", within which the bondholders are themselves one type of contractor. In the corporate nexus, there are two main kinds of contracting parties: the "fixed claimants", who specifically negotiate the terms of each contract they have with others in the firm, and the "residual claimants" who do not negotiate each term, but rely upon a standard statutory structure to define their rights and 
obligations. (True believers assert that the CBCA itself is only a set of default rules representing implied contracts that otherwise would have been negotiated, but for the lack of time, money and convenience. Those conditions may, of course, be the limits to contract theory that justify intervention.)

The advantage of the nexus theory, to be sure, is great clarity and conceptual simplicity if not elegance: it allows for an assessment of the "negotiated" and at least stipulated written rights and duties of those involved in the contractual arrangement. If it meets the proper formalities, the contract becomes part of the ascertainable legal architecture of the firm. They become a series of "atomistic" transactions. Expanding the concept, some groups of contracts form a nexus, which is a firm, and everlarger groups of contracts become a market. Contracts are on the whole exchanges for value, these values form prices, which provide an essential feed-back mechanism to the self-regulation of contracts, firms and markets through the (re)negotiation of still more contracts over time.

A contractual theory of the firm sees directors and senior management as agents of and subordinate to shareholders, which, because of the opportunity for conflicts of interest (self-dealing using the property of another), requires the imposition of a statutory duty to act in the interests of shareholder. (Presumably, such terms would have been negotiated anyway, but for time and convenience, and equality, we might presume, equities sell at a significant premium to their nearest substitutes as a result of the inclusion of this protection.) By protecting the interests of shareholders, the residual claimants - it is said - the firm's value as a whole is maximized as often as possible. Although not perfect, as the bondholders no doubt feel, some say it is the least worst option as a form of ordering corporate affairs.

There are complexities and challenges to this model. There are internecine debates about whether firms are all contracts or only partly contracts and partly "defensive partitions", and there are debates about the delineation of firms from markets and their operation within them. On the whole, however, it is maintained that these contracts are informed by an economic logic, and their enforcement should follow the dictates of that logic. There 
has been so much erudite commentary ${ }^{24}$ on the theory of the corporation as a nexus of contracts, that it needs little effort here to recognize the force and persuasiveness of this approach.

And yet, this is also a reductionist view of the corporation as its mobilization generally reduces the (potentially vast) scope of possible influences on decision-making in corporate relations to the terms of the written documents. The critique of the nexus theory has long been established. ${ }^{25}$ The nexus theory does not seem to explain some firm behaviours ${ }^{26}$, and academic work has explored the influence of other "extra-legal" norms, such as the influence of hierarchical non-contractual relations on intra-firm behaviours. Others ${ }^{27}$ suggest that while there may be contracts, they may not operate to form markets: is there, for instance, a functioning market in management, or not? Sometimes, the critique is framed as one challenging ${ }^{28}$ shareholder primacy on the basis that functionally, a corporation does not operate in the way its legal infrastructure suggests. Even those (formerly) committed to the shareholder primacy and shareholder maximization doctrines have reviewed the effects of recent history - a period loosely associated with triumph of this concept -- and suggested that a broader analysis is required. ${ }^{29}$

${ }^{24}$ Easterbrook, F.H. \& D. R. Fischel, The Economic Structure of Corporate Law (Harvard University Press, 1991).

${ }^{25}$ Bratton, W.W. 'The 'Nexus of Contracts' Corporation: A Critical Appraisal', (1989) 74 Cornell L. Rev. 407-465; Bratton, W.W. 'The Economic Structure of the Post-Contractual Corporation', (1992) 87 Nw. U. L. Rev. 180-215; Deakin, S. 'Squaring the Circle? Shareholder Value and Corporate Social Responsibility in the U.K.' (2002) 70 George Washington Law Review 976-987.

${ }^{26}$ Ben-Ishai, S., A Team Production Model of Canadian Corporate Law, available online at http://www.comparativeresearch.net/servlet/DownloadPDF?paperid=100000035 (last visited June 30, 2008).

${ }^{27}$ Hill, J.G., "Public Beginnings, Private Ends - Should Corporate Law Privilege the Interests of Shareholders?" INTERNATIONAL CORPORATE LAW, MacMillan, ed., Hart Publishing, p. 17, 2000 Available at SSRN: http://ssrn.com/abstract=885222

${ }^{28}$ Hutchinson, A., "Why Shareholder Primacy", Globe and Mail, June 11, 2008 available online

http://osgoode.yorku.ca/media2.nsf/83303ffe5af03ed585256ae6005379c9/4cc1efab41d04 1ca8525746600509ef0! OpenDocument (Last visited June 30, 2008).

${ }^{29}$ Jensen, Michael C., "Value Maximization, Stakeholder Theory, and the Corporate Objective Function" (October 2001). Unfolding Stakeholder Thinking, eds. J. Andriof, et al, (Greenleaf Publishing, 2002). Also published in JACF, V. 14, N. 3, 2001, European 
Some argue that shareholders are the real risk-takers in a corporate nexus, and as such, they are the engines of innovation, growth and capitalism. These conditions may be true for small start-ups and venture capitalists who seek to bring something new to the market but they're not true for venerable blue-chip telecom giants like BCE. Shares of BCE are functionally much more like other claims on revenues of the corporation: they may pay dividends and they may appreciate when traded on the secondary market, they may be bought speculatively on the chance of the convergence of media technologies or the chance of an LBO at a premium of $40 \%$ to its pre-transaction price. But evidence suggests that equities are, in fact, a far less important source of risk capital for most corporations than retained earnings, loans from banks and bondholders, in that order. For this reason, the argument that permitting security-holders to use the oppression remedy raises the cost of capital should be taken with a grain of salt. And, for our purposes, whatever the economics, we observe that shares in a (widely-held, established) corporation are a very special form of contract distant from the liberal ideal, if they are a contract at all.

Perhaps it is fair to say that the continuation of the shareholder primacy debate reflects the merits of arguments on either side. For now, the QCA's treatment of the bondholders' interests in the LBO lies at the centre of the continuing debate about the form by which interests and competences, rights and entitlements are allocated within the corporation. What we propose to add to this wider discussion and specifically the commentary on the QCA decision is, in taking seriously the idea of the corporation as a nexus of contracts, to bring more of the history and development of contract theory into play. Our contention is that an expanded approach to contractual theory and design would contribute to a more convincing contractual concept of the corporation, if that is to be ultimately a workable theory of corporate forms.

Financial Management Review, N. 7, 2001 and in Breaking the Code of Change, M. Beer and N. Norhia, eds, HBS Press, 2000. Available at SSRN: http://ssrn.com/abstract=220671 or DOI: $\underline{10.2139 / \text { ssrn.220671 }}$ 


\section{A BRIEF HERMENEUTIC OF CONTRACT THEORY}

Through the lens of contract the corporation becomes the testing site for the core liberal principle of negotiated autonomy within a complex, dynamic organizational structure. The contentions of negotiated rights inside the firm, however, stress the contractual design to its limits by pushing the principle of "negotiation" into a multifaceted realm, where rights are constituted by parties within a regulatory framework through which the very rights the parties carry out are created and structured (e.g., that overrides freedom of contract by imposing terms), and by the importance of extra-, sub- or non-legal norms on contractual relations (e.g. that supplements or renders ineffective freedom of contract by filling gaps or influencing behaviour of the counter-parties). It is within these regulatory and legally pluralist frameworks that we would begin to examine contracts that constitute the firm.

By seeking to understand and explain the corporation through contracts simpliciter, we tend to homogenize relations through attempts to identify conceptual similarities and by discounting anomalies. Further, we homogenize according to the protocols of the concepts we have selected to deploy. Starting with (say) the proposition that all rights within the corporation are negotiated, the consequence is that the scope and content of these contracts can be found within the written evidence of negotiation alone, instead of through a constructive interpretation of these arrangements within new or changing contexts in which they unfold. This renders a clear picture of contracts within the corporation, but not the reality of the contractual conditions or more broadly the actual operation of the firm. In fact, this idealization and homogenization operates to obscure or de-emphasize the framework around the contract and within which it is negotiated and gets us farther away from a working legal theory of the firm. This "invisibilization" and homogeneisation might continue in an analysis of contracts in the corporation until the contractualized corporation (or theory of it) cannot distinguish between different types of contracts, and we get something like a "cascade of contracts".

We may even begin to believe that everything within the corporation is "negotiated" by idealized contracting parties and that, vice versa, they are all alike, merely "counter-parties". Of course, they are not. Not all 
contracting parties are equally potent and autonomous. Not all contracts are alike, not all are negotiated (including, for the most part, shareholder's contracts) and of course not all contracts entail the same rights and duties, or have the same force on behaviour, or power, even at a very general conceptual level. We have long known ${ }^{30}$ that not all contracting parties engage in the bargaining process with the same pedigree of expertise and freedom from coercion. ${ }^{31}$

There are even deeper implications of the thesis that all rights against the corporation and, vice versa, the directors' responsibilities, are negotiated in particular in the case of sophisticated contract partners as in the case of the BCE debentureholders. This implication is the concept of complete contracting, which follows from the contention of any free-standing principle of freedom of contract. It implies that all which happens within the corporation, in other words that a wide realm of interests, is exclusively governed by contract and, as we have just said, by free and sovereign private actors. Further, we impute to the actors significant power and knowledge, particularly of the future: they must have intended not to include certain terms. This seems to stretch the concept too far. We can readily see shortcomings and omissions in the contracting parties' arrangements. We can assume where possible without court intervention, such gaps are filled. ${ }^{32}$ We will return to these quiddities presently.

Many if not most would acknowledge these basic conditions limiting the liberal ideal we have of contracting. For example, MacIntosh in his discussion of the QCA decision - and we do not mean to overburden his remarks, merely to cite them as exemplary - distinguishes employee contracts from bondholder contracts, and acknowledges that the employee contracts require a statutory architecture to ensure they are fair.

${ }^{30}$ Cohen, M., “The Basis for Contract” (1933) 46 Harv. L. Rev. 553.

${ }^{31}$ Dewey, J. 'The Historic Background of Corporate Legal Personality', (1926) 35 Yale L. J. 655-673; Hale, R.L., "Coercion and Distribution in a supposedly Non-cocercise State", (1923) 38:3 Political Science Quarterly 470; Ireland, P. 'Recontractualising the Corporation: Implicit Contract as Ideology', in D. Campbell, H. Collins and J. Wightman (eds.), Implicit Dimensions of Contract (Hart Publishing, 2003).

32 Bratton, W. W. \& J. McCahery "Incomplete Contracts Theories of the Firm and Comparative Corporate Governance," (2001) 2:2 Theoretical Inquiries in Law Article 7. available at: http://www.bepress.com/til/default/vol2/iss2/art7 (last visited June 30, 2008). 
Reasonable people disagree about the specific design of labour and employment standards law, but few dispute its importance in correcting failures inherent in a purely "contractual" conception of employment relations.

Similarly, shareholders have very curious "contracts" with the other stakeholders in the corporation. They do not negotiate their terms for the most part and they are subject to statutory default rules that allocate risks. Shareholders are sometimes considered "owners" and in a sense "decisionmakers" in very limited ways, but there are libraries of conceptual, analytical and empirical reasons why this is not true in most public or widely-held corporations. They do have a claim to the "residual" assets of the corporation upon wind-up, but that very likely is not the primary motivation behind share purchases and is a very distant form of ownership to most, as we have discussed above in relation to the doctrine of shareholder primacy.

But the homogenization that occurs in conceptualizing the corporation as a contract or cascade of them is an intellectually attractive process; abstracting from large pools of erratic inputs, selecting and making consistent some operational terms, compiling these almost monadic units into a comparative and systematic analysis. We know that it is difficult to idealize contractual relations in the way the theory demands without decontextualizing or "dis-embedding" them from the frameworks we described.

This difficulty leads to analytical tensions in the attempt to articulate models of contractual and firm behaviour that conform to broad evidence, or, in a more continental vein, to adequately describe the operation of legal systems in or around other social systems. The tension comes between selecting and idealizing some form of transaction, some unit of analysis, and the reconciliation of that process with the myriad possible influences on the behaviour we seek to understand. This is a long-standing chestnut of all social sciences and it is particularly piquant in legal theory (or perhaps, legal philosophy) because legal theory invites and even demands normative analysis. Very quickly the business and corporate legal academy pronounced that the SCC had "got it right", saved Canadian capitalism, made it safe for boards to decide things again, and so-on. 
Whether they did or not, this (intellectual) tension is currently unfolding with full force in the rescue of contract from contract law by observing its "death" on one hand ${ }^{33}$ and the celebration of contract as the new mode of transnational governance on the other. ${ }^{34}$ Contract theory makes invisible the constituted nature of arrangements based on contractual rights ${ }^{35}$ while at the same time we see renewed or at least extended interest in contractual conceptualization of legal relations.

This renewed interest is at least in part as a result of the conditions of globalization and consequent de-territorialization of the corporate form we discussed in the introduction to this comment. Under these conditions and in the absence of a supra-national or "top-down" re-territorialization of corporate entities and more specifically, direct regulation of them, the focus of analysis becomes the bi-lateral contract. Relations within the administrative state (the contracting state ${ }^{36}$ ) are being reconceptualized this way, as are transnational commercial relations (the lex mercatoria) and creditor relations. ${ }^{37}$ Even venerable state grants of monopoly rights are being challenged by movements to individually negotiate and control the extension of intangible property - copyright ${ }^{38}$ - outside commercial or forprofit practices. (Note too, the tendency or perhaps requirement to standardize contractual terms and relations in this development).

33 Schwartz, A. \& R. E. Scott, "Contract Theory and the Limits of Contract Law"' (2003) 113 Yale L. J. 541-619; Scott, R.E. "The Death of Contract Law", (2004) 54 UTLJ 369390.

${ }^{34}$ Teubner, G., "Breaking Frames: Economic Globalisation and the Emergence of Lex Mercatoria" . Available at SSRN: http://ssrn.com/abstract=893143.

35 Zumbansen, P. “The Law of Society: Governance Through Contract” CLPE Research Paper 2/2007 available at SSRN: http://ssrn.com/abstract=988610; Kreitner, R., "Fear of Contract" (2004) Wisconsin Law Review, available at SSRN: http://ssrn.com/abstract=632262.

${ }^{36}$ Freeman, J., "The Contracting State”, (2001) 28 Florida State University Law Review 155.

${ }^{37}$ Tung, F., "The New Death of Contract: Creeping Corporate Fiduciary Duties for Creditors" Emory Law and Economics Research Paper No. 07-24 Available at SSRN: http://ssrn.com/abstract=1125364.

${ }^{38}$ Lessig, L, Free Culture (New York: Penguin, 2004) and, of course, freely available online under a Creative Commons license; Benkler, Y., The Wealth of Networks (New Haven: Yale UP, 2007). 


\section{THE BONDHOLDERS CONTRACTING PREDICAMENT}

We have described a problematic of legal or any social science, the tension between the idealization of the subject in analysis and the context which it seeks to understand: put another way, we have described how the contract is a formal reduction of the circumstances in which it is created which does not capture the wider differentiated natures of parties, circumstances and changing conditions. We understand why, as a matter of legal science, we could construct a systematic analysis of contractual relations this way, and some of the frailties associated with it.

The case of the debentureholders is interesting in this light. The core argument of the appellants before the SCC is that they negotiated the terms of the bonds they bought, or if they didn't, they should have. They should not be accorded any broader consideration by the board of BCE. If they did not negotiate protections against the addition of LBO-level debt — so the argument goes - they paid a discount as a result. They took a risk, and the cost of that risk now falls on them. It should fall on them, because they intended it to.

We could and probably should consider institutional bondholders as capable and sophisticated counter-parties with a realistic option not to enter the transaction, and real power to affect the terms of the deal, although the recent history of asset-backed commercial paper leads us to wonder whether this sophistication is over-emphasized in some transactions. This characterization implies that the bondholders should have and probably did acknowledge the possibility of an LBO "event". We also know that covenants restricting new debt or triggering repayment rights in certain events are common devices, and so, contract theory predicts, there must have been other reasons not to include them. Professor MacIntosh suggests that one is price: that the bondholders "virtually certainly" received a discount for not including such conventional protections in the contracts. A rough guide to the cost of including those covenants could be bondholders' losses in the event: for argument's sake, $10 \%$ to $20 \%$ of their value on the market. Some careful research might bear out this discount, we cannot say with certainty. What this price suggests is interesting for contract theory: the cost of adequate protection 
is very high, perhaps even prohibitively expensive. There is at least one study $^{39}$ of bondholder protections that tends to confirm this view: while covenants work pretty well and reflect risks, especially with established issuers, the exception was leveraged buy-outs. However,

exhaustive contracts providing something approaching complete protection against agency costs prove feasible only in relational contexts conducive to ongoing renegotiation over time due to small numbers of lenders operating under reputational constraints...[t]his leaves bondholders confronting a residuum of agency costs and relying on secondary protections like monitoring, exit, diversification, and hedging [emphasis added]. ${ }^{40}$

Under these conditions, we assume bondholders decided to take a risk the appellants urged this theory by arguing that the buyers were "repeatedly warned" that the debentures lacked adequate protections against LBOs, and they took a gamble that BCE would not add \$30B in debt and see the ratings of their existing obligations downgraded. Yet, they would have had very good reason to make that bet, because management stated consistently that they would maintain investment grade ratings on its debt, and presumably bondholders continued to contemplate secondary protections, like exit. In fact, management went so far as to say that they would maintain investment grade ratings on BCE debt because they based their "relationships with bondholders on 'fairness' not literal interpretation of contracts; and that stakeholder interests would be balanced", ${ }^{41}$

Contract theory would ignore management's comments about its commitment to fairness in shaping its financial architecture: that is so much puffery to a contractual view of the corporation. This contractual concept freezes the subjective will of the parties in a single moment of, literally, the issue, while the contractual reality and thus the contract's scope and content evolve over time. In this case, a material change occurred over a very short time: management was approached by private equity investors in February, 2007; rejected the proposal; issued a statement on March 29 to that effect; was put "in play" on April 9 and

39 Bratton, W.W., "Bond Covenants and Creditor Protection: Economics and Law, Theory and Practice, Substance and Process" European Business Organization Law Review (EBOR), available at SSRN: http://ssrn.com/abstract=902910.

${ }^{40}$ Ibid.

${ }^{41}$ As quoted in the QCA judgment. 
management reversed its decision by April $20^{\text {th }}$. That three months is a long time in the financial world, and may have been enough time for institutional holders to exit, hedge or diversify their risk, but those changes would occur 10 or 20 years distant from the point of issue.

Management's sentiments change, interest rates change, strategies do not work out as planned, stock prices move up, or down. Relational contract theory offers valuable lessons in this regard: ${ }^{42}$ no contracting party, not even a sophisticated one, can negotiate and plan and for all arising eventualities with regard to the contractual arrangement's development over time. This, of course, includes the complex consequences of takeover transactions, the economic merits of which - among others - remain anything but uncontested. In fact, numerous studies provide ample evidence that the economic outcomes of takeovers are often different than what either shareholders or management anticipated. ${ }^{43}$ This, in turn, suggests that the contract paradigm, rooted in the will theory, does little to explain the complexity of the full dimensions of contractual arrangements embedded in complex socio-economic situations such as the BCE transaction.

If we discount any real descriptive or explanatory power from this contractualist view, especially as they move over time, its normative content and effect becomes more apparent. Contract theory - in effect, caveat emptor - is not so much a declaration of freedom to contract as an a priori choice of distributive mechanism in the event things go wrong, as we know from experience they inevitably will. We can begin to see the pressure that the contract theory puts on the capacity of the parties to negotiate risks and on the fairness of those negotiations in light of radically changed circumstances.

How has that choice played itself out in the BCE decision? In the zerosum, binary contractual view, losses fall on the creditors. Bondholders saw the market value of their bonds fall by (say) $10 \%$ or $20 \%$, although they

${ }^{42}$ Campbell, D. "The Incompleteness of our Understanding of the Law and Economics of Relational Contract" (2004) Wisc. L. Rev. 645-678.

${ }^{43}$ Romano, R. "A Guide to Takeovers: Theory, Evidence and Regulation" in K. J. Hopt and E. Wymeersch (eds.), European Takeovers. Law and Practice (Butterworths, 1992); Deakin S. \& G. Slinger, "Hostile Takeovers, Corporate Law, and the Theory of the Firm" (1997) 24 Journal of Law and Society 124-151. 
will still get their coupons and principal — unless something unexpected happens, which is why they are now rated at higher risk than prior to the transaction. The insiders get a change of control fee, the service providers get transaction fees, and those "owners" lucky enough to buy stock on the secondary market before, say, February, 2007 see a decent 40\% capital gain.

In a wider view, the debt used to finance the deal has secondary effects which are difficult to estimate with any confidence, and, we think, difficult to contract around easily or efficiently. The rising price of borrowed money will see more internal corporate resources devoted to debt payments, leaving less for other tasks, such as product innovation or, say, the hiring and retention of new talent. It has already eliminated one dividend payment. Should shareholder, creditor and other counter-parties have bought protection? If the exit strategy is a short-term sale to international purchaser, and the future sale price is closely proximate to the transaction price (all this is very speculative), then the effect of this redistribution will be to have shifted economic benefit from existing bondholders to selling shareholders and throw some risk onto future stakeholders in the firm. Those same stakeholders may be farther removed form the locus of decision-making, and domestic bondholders will have a new set of relational requirements with which to cope in the management of their long-term contracts. Indeed, a French private equity firm, Axa Private Equity, has recently proposed that a "code of conduct" be used to guide the allocation of revenues from these transactions. ${ }^{44}$ (The issue for those transactions was the massive payouts made to current management).

Not all of these concerns are or should be the concern of contract law even corporate law — but those are the pressures "pushing in" on the corporate structure through these transactions and their effects. Those kinds of considerations are behind periodic declarations that "relationships with bondholders [are based] on 'fairness' not literal interpretation of contracts; and that stakeholder interests [will] be balanced”.

${ }^{44}$ See Arnold, M. "Private equity chief calls for code on profits" Financial Times, July 14, 2008 available online at http://www.ft.com/cms/s/0/64f9dae2-5113-11dd-b751000077b07658.html?dlbk\&nclick_check=1 (last visited July 14, 2008). 


\section{THE EX-POST-FACTO DECISION-MAKER'S PREDICAMENT}

We return to the decision: the bondholders negotiated a discount against the value of removing debt protections from the debentures: end of story.

The alternative and - it is said - more tragic ending is that courts step in to substitute their contextual and ex-post-facto interpretation of events. Tragic because courts are notoriously responsive to victims, make inconsistent judgments, fail to comprehend the implications of their decisions and are not in a position to cope with the effects of one-off decisions. The tragedy of judicial decision-making is sometimes amplified to suggest that it is a return to welfare-state paternalism (as MacIntosh warns darkly, those "Charter-minded judges") and the end of innovative capitalism itself.

We believe that that line of speculation has very interesting analytical possibilities, insofar as placing in stark relief how the retreat of an administrative state can shift attention away from the merits of an issue and onto the personalities of the courts. But welfare state paternalism is not en vogue ${ }^{45}$ state policy today and not what is at issue here. On the whole courts do not and should not substitute for business decisions: here we are ad idem with MacIntosh, and we note the development of the business judgment rule as one of several techniques for limiting inappropriate intervention when someone is handed a loss.

No doubt many judicial decision-makers feel the same way: there are good reasons why the SCC has not, to date, ventured much into corporate constitutional questions. These decision-makers are, moreover, put in a difficult position by the contractual theory of the corporation: bondholders are perhaps not bleeding victims but from time to time courts face plaintiffs in real hardship, they are urged to ignore the post-contractual context of the relationship and interpret documents with concepts

${ }^{45}$ Zumbansen, P. "Law after the Welfare State: Formalism, Functionalism and the Ironic Turn of Reflexive Law" CLPE Research Paper No. 13/2008 Available at SSRN: http://ssrn.com/abstract=1128144. 
developed in another age. They have little ability to manage the outcomes of their decisions, unlike the contracting parties.

Another view, though, is that where intervention is proper or required, contracts, or at least those very special "contracts" that form the relationships of a corporation, need to be managed and interpreted because they form large institutions in our economy. In this light, we might ask that what courts do is not to be paternal to the parties by substituting its own wisdom, but make - as do the parties involved most of the time bargains on the future.

We see similar and related reconceptualizations ${ }^{46}$ in corporate theory in the analysis of "extra-legal" or informal norms in the balancing of stakeholder interests, and in corporate governance practices in the adoption of several layers of codes of conduct that surround and inform the more formal and legally rigid structure of the corporation. We see a similar reconceptualization in securities law. Where once it focused more on disclosure at the time of issue - a point-in-time regulation of rights and obligations by statute - we now see some more attention paid to appropriate continuous disclosure, and management of the consequences accordingly. In this respect, corporate statutes themselves become eclipsed by the world of securities regulation, which makes sense if we view most security-holders claims as bundles of rights to streams of revenues, and not as residual property owners.

\section{FROM SHAREHOLDER PRIMACY TO A FUNCTIONAL APPROACH}

These developments are sometimes contentious, but they point to the "sources" of law and one way in which wider interests in the corporation can be articulated if not imposed.

46 Blair, M. M. \& Stout, L.A.., "A Team Production Theory of Corporate Law" (1999) 85:2 Virginia Law Review 248-328 available at SSRN: http://ssrn.com/abstract=425500 or DOI: $10.2139 /$ ssrn.425500. 
In the narrow confines of the BCE decision, the analysis can be reduced to a zero-sum tradeoff between fixed and residual claimants. It is tempting to do so. That description has conceptual clarity and formal symmetry, which is appealing to a decision-maker and to a theorist: it might even be fair in this case. Bondholders are often not the most sympathetic plaintiffs even if they represent someone's retirement savings held in mutual or pension funds - and we are not suggesting that they have some particular privilege or special infirmity. They might: we do not speculate.

But from the perspective of a social choice - and we do contend that freedom of contract and the CBCA are social choices over which we can make policy - the purely contractual view of these relations often comes at the cost of a better understanding of the factors influencing that particular contractual relationship, and excludes a wider range of ways to cope with vagaries arising within them. The parties investing in any company will make bargains on the firm's development, which will unfold within a framework that cannot alone be described by what parties wrote into their contracts. Whenever decision-making is required, at the point of investment, at some re-negotiation of terms, at a fundamental transaction of the firm, at a regulatory intervention, or in disputes brought before courts, such contracts should be examined with caution. But where action must be taken, good decisions will be informed by consideration of the stakeholders' interests, sometimes notwithstanding the terms of their debentures or employment contracts or restrictions on shares. This is a practical imperative and goes well beyond shareholder primacy (although it limits it), or calls for the SCC to re-interpret Wise in keeping with the takeover line of case law, or suggestions that the Court should explicitly import the Revlon rule from U.S. jurisprudence. It is an emerging reality of modern global corporate life.

As the corporate governance debate continues to transnationalize, ${ }^{47}$ the assessment of corporate law's 'anatomy ${ }^{48}$, is being transformed from a

47 The reference to 'foreign' materials, even in domestically oriented corporate law scholarship, has become second nature: see a powerful, recent illustration out of Germany, reviewing case law and scholarship on directors' duties from six jurisdictions: Lars Klöhn, 'Interessenkonflikte zwischen Aktionären und Gläubigern der Aktiengesellschaft im Spiegel der Vorstandspflichten’, (2008) ZGR Zeitschrift für das gesamte Unternehmensrecht 110-158. 
traditional domestic and comparative perspective into a multi-faceted, interdisciplinary inquiry into the regulatory conditions of modern-day corporations. These conditions can no longer be captured with reference alone to path-dependent law and policy-making trajectories in a given jurisdiction. ${ }^{49}$ Instead, corporate governance has become a polycontextual regulatory field marked by a complementarity of different normentrepreneurs in and outside of the nation-state, altogether contributing to an extremely layered and textured body of norm shaping corporate behavior. The evolving nature of corporate governance as 'transnational legal pluralism, ${ }^{50}$ presents just as many challenges to the traditional analytical framework to study corporate law as it presents opportunities for a more effective inquiry into the dynamics of change in this regulatory regime.

${ }^{48}$ Kraakman, R. et al., The Anatomy of Corporate Law. A Comparative and Functional Approach (Oxford University Press, 2004).

${ }^{49}$ See only Roe, M. 'Comparative corporate governance', in P. Newman (eds.), The New Palgrave Dictionary of Economics and the Law (Palgrave Macmillan, 1998), and the contributions to Gordon J.N. \& M. J. Roe (eds.), Convergence and Persistence in Corporate Governance (Cambridge University Press, 2004).

50 Zumbansen, P."'New Governance' in European Corporate Law Regulation as Transnational Legal Pluralism" (April 2008). CLPE Research Paper No. 15/2008 Available at SSRN: http://ssrn.com/abstract=1128145. 